

\title{
Chemical and Biological Pretreatments on Sugarcane Bagasse to Enhance its Enzymatic Hydrolysis.
}

\author{
Christian A. Hernández, ${ }^{[\mathrm{aj}}$ Fabio Ziarelli, ${ }^{[b]}$ Isabelle Gaime, ${ }_{1}^{\left[{ }^{[c]}\right.}$ Anne Marie Farnet Da Silva, ${ }^{\left[{ }^{[d]}\right.}$ \\ Gabriela García, ${ }^{[\mathrm{e}]}$ José A. García-Pérez, ${ }^{[f]}$ Beatriz Gutiérrez-Rivera, ${ }^{[g]}$ and Enrique Alarcón*[e]
}

Alkaline and biological lignocellulose pre-treatments are commonly used to enhance enzymatic hydrolysis and improve ethanol production. In this study, ${ }^{13} \mathrm{C}$ CPMASNMR spectroscopy was used to describe changes in sugarcane bagasse (SCB) pretreated with $\mathrm{NaOH}, \mathrm{Ca}(\mathrm{OH})_{2}$ and with Pycnoporus sanguineus. Changes in the contents of alkyl C, Carboxyl C, Aromatic C (tertiary, quaternary and p-hydroxyphenyl C), O-alkyl C, amino acids, ergosterol and chitin, as well as in the crystallinity index of cellulose were observed. Through a multivariate analysis, relations between changes in the chemical composition of SCB and enzymatic hydrolysis were established. $P$. sanguineus promotes better lignin decay, glucose release and hydrolysis yields than chemical pre-treatments, and increases the amount of amino acids and ergosterol in SCB, while $\mathrm{NaOH}$ increases the cellulose crystallinity index. The hydrolysates were fermented with Saccharomyces cerevisiae for $96 \mathrm{~h}$, and analysed through HPLC. The initial composition of the hydrolysates $\left[\mathrm{mg}^{-\mathrm{ml}^{-1}}\right.$ ] and biomass production (cells. $\mathrm{ml}^{-1}$ ) were then related to the ethanol production and fermentation yields. We found that ethanol production and fermentation yields were negatively correlated with cell growth in Saccharomyces, but positively correlated with glucose consumption in the $P$. sanguineus pretreatment. We conclude that the biological pre-treatment using $P$. sanguineus in the conditions hereby described, has a potential to increase ethanol productivity. [a] Dr. C. A. Hernández

Universidad Politécnica de Huatusco,

Unidad Académica de Orizaba

Calle Oriente 4A, C.P. 94740, Orizaba, Veracruz, Mexico;

[b] Dr. F. Ziarelli

Aix Marseille Université, Faculté des Sciences et Techniques de Saint-Jérôme

Spectropole, PO box 512,

Avenue Escadrille Normandie Niémen, 13397 Marseille cedex 20, France

[c] Dr. I. Gaime

Equipe Ecotechnologies et Bioremediation,

IMBE, UMR CNRS 7263, IRD 237, Faculté des Sciences et Techniques de St. Jérôme,

Aix Marseille Université, Marseille, France.

[d] Dr. A. M. Farnet Da Silva

Equipe Systèmes Microbiens IMBE, UMR CNRS 7263, IRD 237,

Faculté des Sciences Techniques de St. Jérôme, Aix Marseille Université, Marseille, France.

[e] G. García, Dr. E. Alarcón

Instituto de Biotecnología y Ecología Aplicada (INBIOTECA), Universidad Veracruzana,

Av. de las culturas veracruzanas 101, Col. Emiliano Zapata, C.P. 91090, Xalapa Veracruz, Mexico

E-mail: enalarcon@uv.mx

[f] Dr. J. A. García-Pérez

Faculty of Biology, Universidad Veracruzana,

Cto. Gonzalo Aguirre Beltrán s/n, Col. Emiliano Zapata, Xalapa, Veracruz 91090, Mexico.

[g] Dr. B. Gutiérrez-Rivera

Instituto Tecnológico Superior de Tierra Blanca, Tierra Blanca, Veracruz 95180, Mexico.

\section{Introduction}

Sugarcane bagasse $(\mathrm{SCB})$ is a promising source of raw material for bioethanol production ${ }^{[1]}$ through enzymatic hydrolysis. The efficiency of this method depends on a pre-treatment aimed at reducing the crystallinity of the raw material, as well as its hemicellulose and lignin content, lignin being a cellulase adsorbent. ${ }^{[2,3]}$ Thus, for an efficient lignocellulose hydrolysis, a pretreatment is necessary in order to decrease lignin, the cellulose-crystallinity index, and the hemicellulose content.

A good pre-treatment includes alkaline agents like $\mathrm{NaOH}$, $\mathrm{Ca}(\mathrm{OH})_{2}$ and $\mathrm{KOH}^{[4]}$ Alkali attacks lignin via saponification of ester-linkages between cellulose and hemicellulose with lignin, ${ }^{[5]}$ although it may generate alkaline-cellulose by ion exchange. ${ }^{[6]}$ Also, as opposed to acids, alkaline agents for biomass delignification rarely generate compounds that are harmful to microorganisms. ${ }^{[7]}$

Biological pre-treatments using live fungi, on the other hand, have been found to enhance enzymatic hydrolysis. ${ }^{[8]}$ Fungi (mainly white-root fungi) can oxidize lignin via phenoloxidase enzymes (i.e., laccases, Mn-peroxidases, lignin peroxidases) and produce cellulases and hemicellulases (e.g. xylanases), decreasing the stock of polysaccharides and, consequently, the production of bioethanol. And since fungi also transform some lignocellulose material into fungal biomass, the outcome is a different raw material altogether. The structural characterization of SCB fibres pre-treated with live fungi is key to the understanding of how fungal enzymes affect fibre composition, and how this structural composition affects in turn the hydrolysis/fermentation processes downstream. Classical methods for fibre analysis based in subsequent 


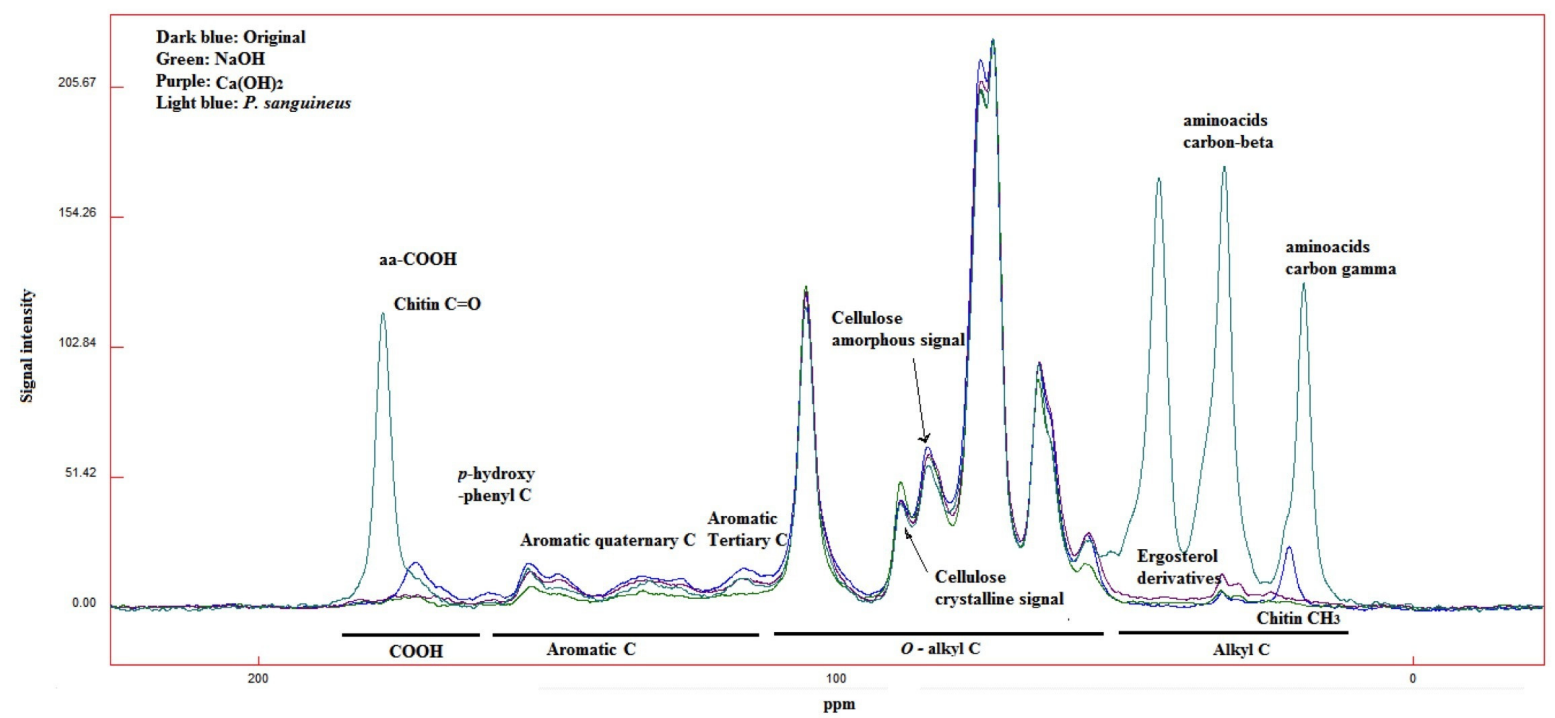

Figure 1. 13C CPMASNMR spectra of sugarcane bagasse before after pretreatments (indicated with colours). Important regions are shown.

detergent hydrolysis (e.g. Van Soest and Wine ${ }^{[9]}$ ) are not enough to explain the complex modifications of lignocellulose fibre by fungi or chemical pre-treatments. Thus, for lignocellulose characterization, the use of other techniques, such as near infrared spectroscopy (FTIR) and ${ }^{13} \mathrm{C}$ solid-state nuclear magnetic resonance (NMR), are preferred.

${ }^{13} \mathrm{C}$ CPMASNMR spectroscopy is a powerful technique of analysis, successfully used on soil litter, ${ }^{[10]}$ the lignification process, ${ }^{[11]}$ and the extent of condensation in lignin characterisation, ${ }^{[12]}$ and can also be used to evaluate changes in fungal biomass. ${ }^{[13]}$ Solid-state NMR allows for chemical analysis to be carried out in a natural state, and is an excellent choice for samples with restricted solubility, as are lignin residues, or when the physical structure of cellulose is to be examined. ${ }^{[14]}$ Therefore, the aim of this study was to characterize SCB fibre by ${ }^{13} \mathrm{C}$ CPMASNMR spectroscopy after a biological pre-treatment, using the fungus Pycnoporus sanguineus and two alkaline pre-treatments with $\mathrm{NaOH}$ and $\mathrm{Ca}(\mathrm{OH})_{2}$. For more details see $\mathrm{SI}$. After that, pre-treated SCB was hydrolysed with Aspergillus niger cellulases and fermented with Saccharomyces cerevisiae, and the yields of both steps were related to their structural composition using multivariate statistical methods.

\section{Results and Discussion}

\section{Chemical shifts in SCB submitted to different pre-treatments}

Both chemical and biological pre-treatments lead to changes in the chemical composition of SCB. The O-alkyl C signal (45$110 \mathrm{ppm}$ ) corresponds to the carbohydrate (i.e., holocellulose) content of $\mathrm{SCB}$, indicating that the original composition of $\mathrm{SCB}$ had $79.76 \%$ holocellulose, and that after an alkaline pretreatment the proportion increased to $88.86 \%$ with $\mathrm{NaOH}$, and to $84.13 \%$ with $\mathrm{Ca}(\mathrm{OH})_{2}$ (Figure 1). Conversely, biological pre- treatment decreased the amount of holocellulose to $50.65 \%$. The aromatic $\mathrm{C}$ region, which corresponds to lignin, had an original proportion of $12.87 \%$, and the pre-treatments decreased this value as follows: $\mathrm{Ca}(\mathrm{OH})_{2}$ to $10.26 \%, \mathrm{NaOH}$ to $7.03 \%$, and $P$. sanguineus to $6.53 \%$. All treatments led to a decrease in aromatic $C$ content, but the highest lignin decay was achieved with $P$. sanguineus (Table 1 ).

The values of the regions Carboxyl $C$ and Alkyl $C$ are associated to proteins and lipids, and their peaks correspond to the acetate groups in the hemicellulose that appears in this region. Taking them together, they were very low in the original composition of SCB $(3.57 \%$ and $2.45 \%$, respectively). Alkaline pre-treatments diminish the amount of Carboxyl $\mathrm{C}$ to $1.48 \%$ $(\mathrm{NaOH})$ and $1.60 \%\left[\mathrm{Ca}(\mathrm{OH})_{2}\right]$, and in general they did not affect the Alkyl $\mathrm{C}$ region. On the other hand, the pre-treatment with $\mathrm{P}$. sanguineus strongly increased both regions: Carboxyl $C$ increased to $9.31 \%$, and Alkyl C to $33.49 \%$ (Figure 1 ).

The signals corresponding to the $C \alpha, C \beta$ and $C \delta$ of amino acids increased with the treatments with $P$. sanguineus from $5.61 \%$ to $18.38 \%$ (as did the signals corresponding to chitin and the $C \gamma$ of amino acids, from $3.47 \%$ to $8.49 \%$ ), whereas alkaline treatments diminished or did not change those signals (Figure 1). The ergosterol signal was near to 0 in the original composition of SCB, and remained the same after the alkaline pre-treatments. However, when $P$. sanguineus was used, ergosterol increased from $0.24 \%$ to $4.33 \%$. Thus, $P$. sanguineus transformed a portion of SCB into fungal biomass, as was hypothesized at the beginning.

The proportion of amorphous cellulose and crystalline cellulose, estimated by the signal position of the C 4 of pyranoglucose ${ }^{[20]}$ indicates that SCB has an original crystallinity index (Cl) of 0.29 . This value changed slightly according to the pretreatments employed: SCB pre-treated with $\mathrm{NaOH}$ increased its $\mathrm{Cl}$ to 0.32 , decreased to 0.27 when $\mathrm{Ca}(\mathrm{OH})_{2}$ was used, and 


\begin{tabular}{|c|c|c|}
\hline Component & Position (ppm) & Reference \\
\hline Alquil-C region & $0-45$ & [15] \\
\hline Aminoacids carbon $\gamma$ & $16.1-24.7$ & [15] \\
\hline Aminoacids carbon $\beta$ & $28-37.6$ & [15] \\
\hline $\mathrm{CH}_{3}$ of quitin & 23.32 & [16] \\
\hline $\begin{array}{l}\text { Ergosterol and deri- } \\
\text { vates } C 4, C 24, C 20 \text {, } \\
\text { C13, C10 }\end{array}$ & $37.05-42.85$ & {$[17,18,19]$} \\
\hline \multirow{4}{*}{$\begin{array}{l}\text { O-alquil C Region } \\
\text { Cellulose crystallinity } \\
\text { index }\end{array}$} & $45-110$ & \\
\hline & $\begin{array}{l}\text { Is calculated by dividing the total } \\
\text { area of the crystalline peak ( } 87 \text { to }\end{array}$ & \\
\hline & $\begin{array}{l}93 \mathrm{ppm}) \text { by the total area assigned } \\
\text { to the } C_{4} \text { peak }(80-93 \mathrm{ppm}) \text {. }\end{array}$ & [20] \\
\hline & $53.5-61.3$ & \\
\hline Aminoacids carbon $\alpha$ & $47.5-49.2$ & [15] \\
\hline Aminoacids carbon $\delta$ & $81.2-81.7$ & [15] \\
\hline \multirow[t]{2}{*}{ Xylane C4 } & & [21] \\
\hline & $110-160$ & \\
\hline Aromatic C Region & $110-123$ & \\
\hline Aromatic tertiary $C$ & $123-160$ & [22] \\
\hline Aromatic quaternary $\mathrm{C}$ & $157-162$ & [22] \\
\hline \multirow[t]{2}{*}{ p-hydroxyphenyl } & & [22] \\
\hline & $160-190$ & \\
\hline Carboxil-C Region & 173.7 & \\
\hline Quitin C $=0$ & $170.9-174.5$ & [16] \\
\hline $\begin{array}{l}\text { Carbon of } \mathrm{COOH} \text { from } \\
\text { aminoacids }\end{array}$ & & [15] \\
\hline
\end{tabular}

remained unchanged with the $P$. sanguineus pre-treatment. This indicates that $\mathrm{NaOH}$ promotes amorphous cellulose removal, which may affect the performance of hydrolysis. Finally, the signals of aromatic carbons decreased in all treatments, $P$. sanguineus being the treatment that obtained the highest decrease of aromatic carbons, followed closely by the SCB pretreated with $\mathrm{NaOH}$, and then by the $\mathrm{SCB}$ pre-treated with $\mathrm{Ca}$ $(\mathrm{OH})_{2}$.

\section{Hydrolysis step}

In all treatments, cellulase activity decreased rapidly within the first 24 hours, while total sugar content increased within the first 24 hours, remaining almost unchanged afterwards (Figure 2).

The area under the curve of FPU activities showed that when SCB pre-treated with $P$. sanguineus (99.21 FPU for $96 \mathrm{~h}$ ) and $\mathrm{NaOH}$ (115 total FPU for $96 \mathrm{~h}$ ) was hydrolysed, the enzymatic stability was higher. Conversely, less FPU activity was registered in treatments with $\mathrm{SCB}$ pre-treated with $\mathrm{Ca}(\mathrm{OH})_{2}$ (56.91 total FPU in $96 \mathrm{~h}$ ), and with untreated SCB (57.33 total FPU for 96 hours). Cellulase stability was positively correlated with O-alkyl C, Xylan C4 and Cellulose crystallinity, and negatively correlated with Alkyl C, Carboxyl C, carbon amino acids, chitin and ergosterol (Table 2 ).

Like total reducing sugars release, glucose production was faster within the first $24 \mathrm{~h}$ of hydrolysis. SCB pre-treated with $P$. sanguineus produced the highest amount of glucose $(29.76 \pm$
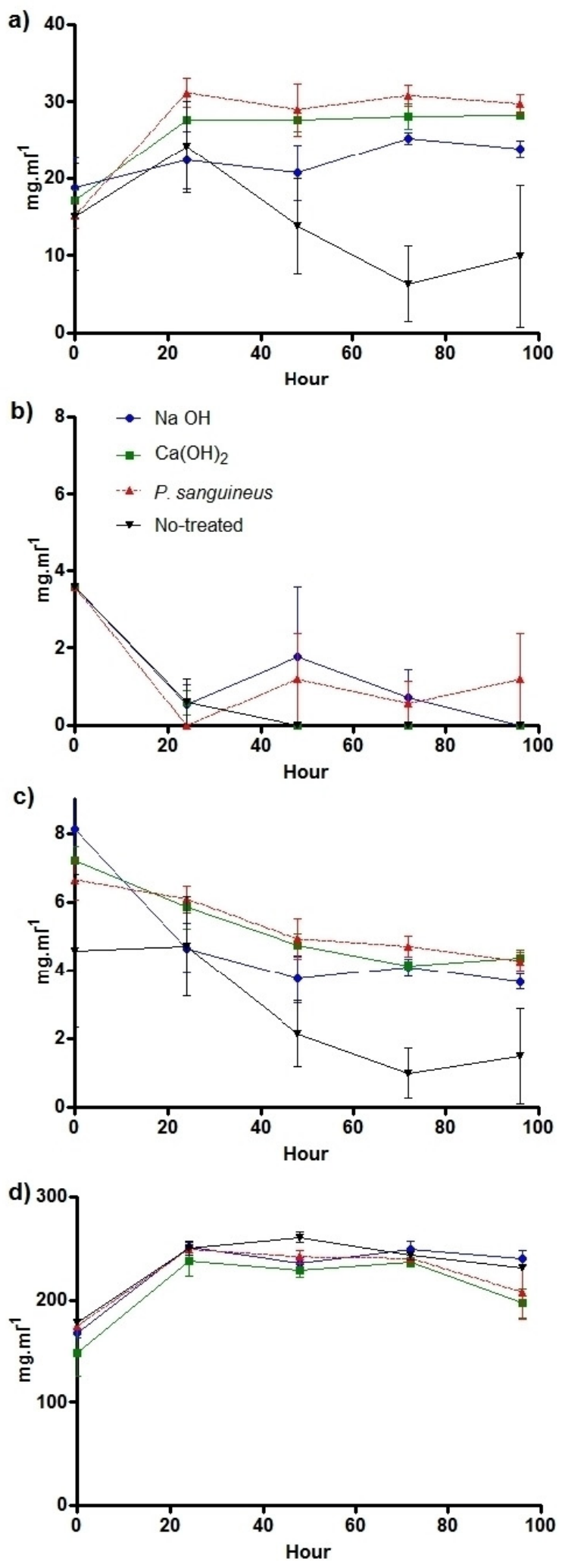

Figure 2. Kinetics of the different parameters measured during the hydrolysis phase. a) glucose released, b) cellulase activity (FPU), c) saccharose released, d) total reducing sugars released. Different colours indicate different pretreatments. Middle points represent the means, and bars the standard error. 


\begin{tabular}{|c|c|c|c|c|}
\hline Compounds & $\begin{array}{l}\text { Cellulase } \\
\text { stability }\end{array}$ & $\begin{array}{l}\text { Glucose } \\
\text { released }\end{array}$ & $\begin{array}{l}\text { Hydrolysis } \\
\text { yield }\end{array}$ & $\begin{array}{l}\text { Saccharose fi- } \\
\text { nal content }\end{array}$ \\
\hline Alkyl C & -0.592 & 0.746 & 0.923 & 0.435 \\
\hline Carboxyl C & -0.500 & 0.545 & 0.786 & 0.158 \\
\hline Aromatic C & 0.117 & -0.653 & -0.668 & -0.739 \\
\hline O-alkyl C & 0.597 & -0.634 & -0.847 & -0.254 \\
\hline Aa $\gamma+$ chitin & -0.478 & 0.489 & 0.742 & 0.087 \\
\hline $\mathrm{aaC} \beta \delta \alpha$ & -0.675 & 0.797 & 0.950 & 0.483 \\
\hline Ergosterol & $\begin{array}{l}-0 . \\
99\end{array}$ & 0.762 & 0.932 & 0.459 \\
\hline $\begin{array}{l}\text { Xyl } \\
\text { ne C4 }\end{array}$ & 0.497 & -0.593 & -0.823 & -0.232 \\
\hline Cellulose Cl & 0.793 & -0.311 & -0.268 & -0.036 \\
\hline $\begin{array}{l}\text { Tertiary aromatic } \\
\text { C }\end{array}$ & 0.257 & -0.757 & -0.740 & -0.833 \\
\hline $\begin{array}{l}\text { Quaternary aro- } \\
\text { matic } C\end{array}$ & 0.057 & -0.604 & -0.632 & -0.694 \\
\hline $\begin{array}{l}\text { p-hydroxyphenyl } \\
\text { aromatic C }\end{array}$ & 0.247 & -0.736 & -0.633 & -0.908 \\
\hline
\end{tabular}

$\left.2.2 \mathrm{mg} \cdot \mathrm{ml}^{-1}\right)$, followed by SCB pre-treated with $\mathrm{Ca}(\mathrm{OH})_{2}(28.19$ $\pm 0.45 \mathrm{mg} \cdot \mathrm{ml}-1), \mathrm{NaOH}\left(23.84 \pm 2.0 \mathrm{mg}^{-1} \mathrm{ml}^{-1}\right)$, and the untreated SCB (9.95 $\pm 15.93 \mathrm{mg}^{-1} \mathrm{ml}^{-1}$ ) (Figure 2). Saccharose content decreased slightly during SCB hydrolysis in all treatments (Figure 2), reaching a final concentration of $4.38 \pm$ $0.36 \mathrm{mg} \cdot \mathrm{ml}^{-1}$ when pre-treated with $\mathrm{Ca}(\mathrm{OH})_{2}, 4.26 \pm$ $0.4 \mathrm{mg} \cdot \mathrm{ml}^{-1}$ when pre-treated with $P$. sanguineus, $3.66 \pm$ $0.3 \mathrm{mg} \cdot \mathrm{ml}^{-1}$ when pre-treated with $\mathrm{NaOH}$, and $1.48 \pm$ 2.4 mg.ml-1 when untreated (Figure 2).

The glucose released was positively correlated with alkyl C, carboxyl C, amino acids content, chitin and ergosterol. These variables positively affected the hydrolysis yield too (Table 2 ). Meanwhile, cellulose crystallinity, aromatic C, and tertiary, quaternary and p-hydroxyphenyl aromatic $C$, negatively affected glucose release and the hydrolysis yield. Saccharose was positively correlated with the variables associated to the presence of fungal biomass, and negatively correlated with lignin compounds (aromatic carbons) (Table 2).

The treatment that promoted the highest glucose and hydrolysis yield was $P$. sanguineus.

The highest hydrolysis yield was achieved when SCB was pre-treated with $P$. sanguineus, followed by pre-treatments with $\mathrm{Ca}(\mathrm{OH})_{2}$ and $\mathrm{NaOH}$. The lowest yield was obtained with untreated SCB. The fungal biomass gain did not negatively affect enzymatic hydrolysis. In fact, the highest hydrolysis yield was obtained with SCB pre-treated with $P$. sanguineus. The effect of proteins or lipids on cellulase catalysis is not well documented, but it is known that some lipids can act as surfactants, and avoid the absorption of cellulases by cellulose, increasing the hydrolysis yield. ${ }^{[23,24]}$ Some proteins, like bovine serum albumin, can perform the same role. ${ }^{[25]}$

Thus, the enrichment of proteins and ergosterol by the pretreatment with $P$. sanguineus lead to a decrease in the absorption of cellulase by the SCB fibre, improving enzymatic hydrolysis. The decay in the aromatic $\mathrm{C}$ and $\mathrm{O}$-alkyl $\mathrm{C}$ regions in this pre-treatment are mainly due to the production of laccases and cellulases (as previously reported ${ }^{[27]}$ ). Many authors suggest that this fungus is a good producer of laccase, ${ }^{[26,28]}$ and therefore an excellent choice for delignification processes. ${ }^{[29]}$

According to our Principal Component Analysis, the hydrolysis yield was mainly affected by the content of aromatic C and xylan C4, which, as previously reported, ${ }^{[2]}$ corresponds to the content of lignin and hemicellulose. The cellulose crystallinity index $(\mathrm{Cl})$ was negatively related to the hydrolysis yield, according to Mussato et al... ${ }^{[3]}$ In this study, the pre-treatment with $\mathrm{NaOH}$ increased $\mathrm{Cl}$, which is related to lower hydrolysis, compared to the SCB pre-treated with $P$. sanguineus. Pretreatments with $\mathrm{NaOH}$ and $\mathrm{Ca}(\mathrm{OH})_{2}$ (of less effect) increased cellulose crystallinity, but also increased the $O$-alkyl region and cellulase stability. Untreated SCB had the highest amounts of lignin compounds, and was negatively associated to the release of glucose and the hydrolysis yield (Figure 3).

\section{Fermentation step}

As with enzymatic hydrolysis, SCB pretreated with $P$. sanguineus had the highest fermentation yield and the second highest production of ethanol. Differences in the hydrolysis yield led to differences in the initial glucose content of the fermentation cultures (Figure 3). Glucose decreased near to $0 \mathrm{mg}^{-1} \mathrm{ml}^{-1}$ in all treatments after $48 \mathrm{~h}$ of culturing with $\mathrm{S}$. cerevisiae, while saccharose metabolized more slowly (Figure 3).

On the other hand, S. cerevisiae biomass (Figure 4) and ethanol increased after 96 h. S. cerevisiae cell growth (biomass) was positively correlated with the glucose consumed, but negatively related with the fermentation yield and ethanol production (Table 3 ).

A negative effect of hydrolysates pretreated with $P$. sanguineus on S. cerevisiae biomass was observed, which could be related to a secondary metabolite produced by fungus during the pretreatment. Cinnabarin and poliporin, produced by $P$. sanguineus, have antimicrobial properties; ${ }^{[30,31]}$ however, non-antifungal metabolites have been reported for this fungus. In fact, hydrolysed SCB pre-treated with $P$. sanguineus does not completely inhibit the growth of $S$. cerevisiae, although it does induce cell compilation. This interesting phenomenon needs further study.

SCB hydrolysates pre-treated with $\mathrm{NaOH}(3.26 \pm 0.3 \mathrm{mg}$ $\left.\mathrm{ml}^{-1}\right)$ and $P$. sanguineus $\left(2.99 \pm 0.2 \mathrm{mg} \cdot \mathrm{ml}^{-1}\right)$ were the ones that produced more ethanol, followed by untreated SCB $(2.11 \pm$ $\left.0.8 \mathrm{mg} \cdot \mathrm{ml}^{-1}\right)$ and SCB pre-treated with $\mathrm{Ca}(\mathrm{OH})_{2}(1.50 \pm$ $0.3 \mathrm{mg}^{-1} \mathrm{ml}^{-1}$ ) (Figure 3). The highest fermentation yield was attained from the hydrolysate of SCB pre-treated with $P$. sanguineus, followed by untreated $\mathrm{SCB}, \mathrm{SCB}$ pre-treated with $\mathrm{NaOH}$, and, finally, SCB pre-treated with $\mathrm{Ca}(\mathrm{OH})_{2}$.

No strong relations were observed between those variables measured with ethanol production and fermentation yields. Nevertheless, a PCA biplot indicates that the hydrolysed composition resulting from SCB pre-treated with $P$. sanguineus reached better ethanol and fermentation yields (Figure 4), while the least efficient pre-treatment was that with $\mathrm{Ca}(\mathrm{OH})_{2}$.

Having examined the effects of alkaline and biological pretreatments on the downstream process, we suggest that when 
a)

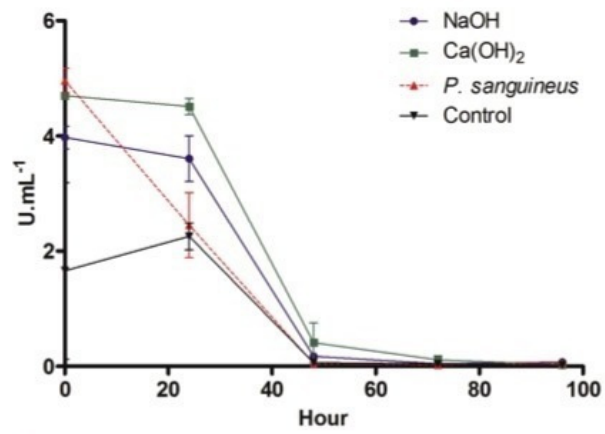

b)

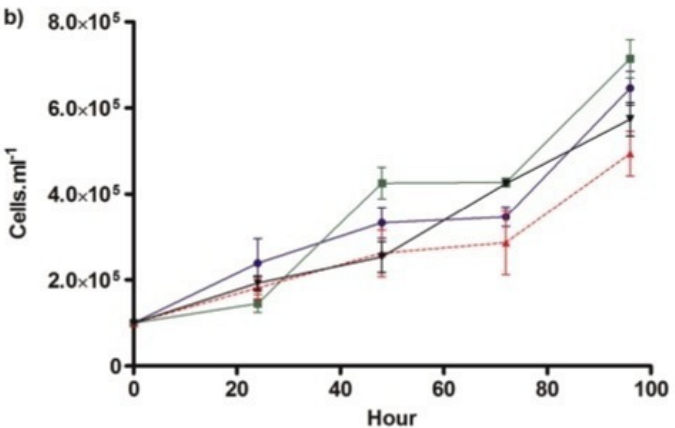

c)

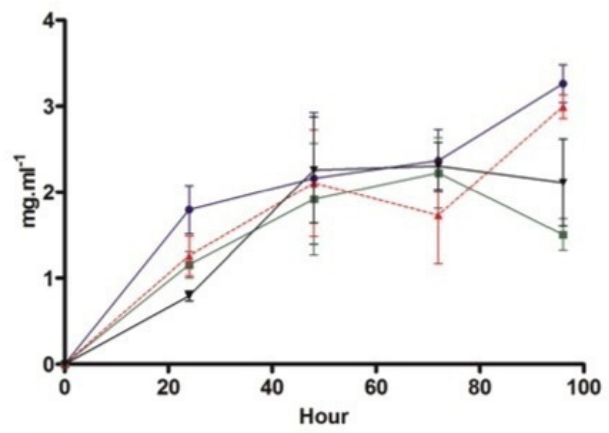

d)

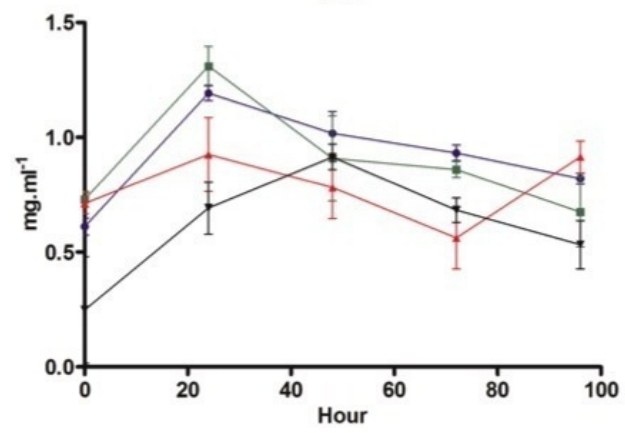

Figure 3. Kinetics of the different parameters measured during fermentation. a) glucose consumption, b) S. cerevisiae cell growth, c) ethanol production, d) saccharose consumption. Different colours indicate different pretreatments. Middle points represent the means, and bars the standard error.

the aim is to produce ethanol, the use of $P$. sanguineus is preferable to the use of $\mathrm{NaOH}$ or $\mathrm{Ca}(\mathrm{OH})_{2}$, since it leads to higher hydrolysis and fermentation yields than alkali treatments. Further studies will focus on the effect of ergosterol and fungal proteins on cellulase catalysis, and the use of other fungus in the SCB pre-treatment.

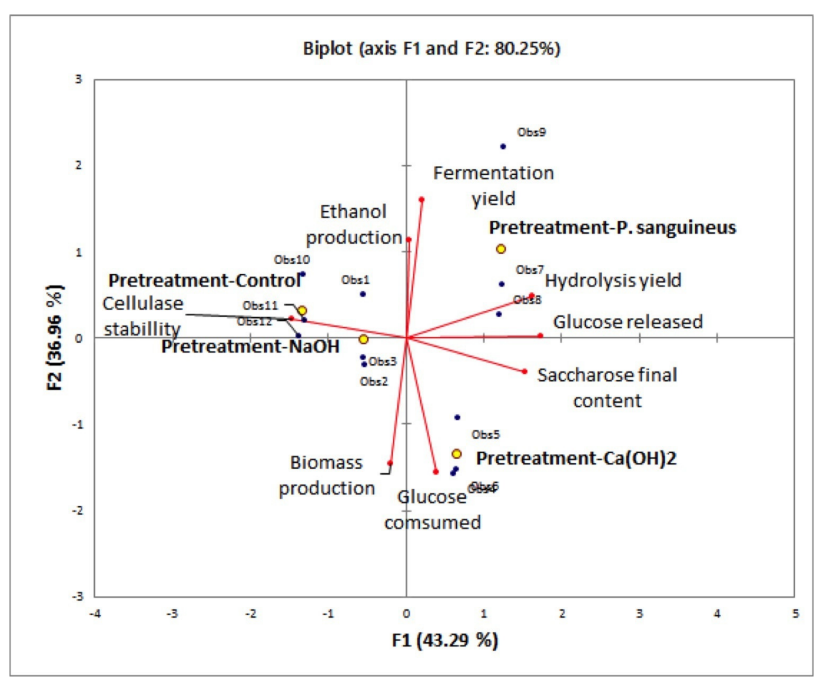

Figure 4. Principal component analysis. The biplot shows the relationship between the different pre-treatments (qualitative variables) with all the parameters measured during hydrolysis and fermentation.

\section{Conclusions}

In summary, both alkaline and biological pre-treatments were able to decrease the intensity of aromatic C (lignin) signals. However, biological pre-treatments converted a portion of the O-alkyl C (carbohydrates) into fungal biomass (lipids and proteins). The ergosterol and protein gained by the SCB fibre by the pre-treatment with $P$. sanguineus might be a positive factor to enhance the hydrolysis yield. These beneficial effects include better fermentation yields than the ones obtained by hydrolysates from SCB pre-treated with alkaline solutions.

\section{Supporting Information Summary}

For experimental details, such as chemical and biological treatments, enzymatic hydrolysis and fermentation, and analytical methods ( ${ }^{13} \mathrm{C}$ CPMASNMR), and statistics, please refer to the Supporting Information (SI).

\section{Acknowledgements}

The authors would like to thank the anonymous reviewers of this paper, as well as the Universidad Veracruzana for its support, the academic group Structure and Functioning of Ecosystems (CAUVER-324), and also to the biologist F. RamírezGuillén, from INECOL A.C., Xalapa, Mexico, for the taxonomical identification of the fungus. Finally, authors would like to thank to the ECOS-NORD-CONACYT-ANUIES project (M13 A02) for the financial support.

\section{Conflict of Interest}

The authors declare no conflict of interest. 
Keywords: alkaline pretreatment - bioethanol - cellulose crystallinity $\cdot$ Pycnoporus sanguineus

[1] C. A. Cardona, J. A. Quintero, I. C. Paz. Bioresour. Technol. 2010, 101(13), 4754-4766.

[2] M. Hall, P. Bansal, J. H. Lee, M. J. Realff, A. S. Bommarius. FEBS Journal 2010, 277, 1571-1582.

[3] S. I. Mussato, M. Fernandes, A. M. F. Milagres, I. C. Roberto. Enzyme Microb. Technol. 2008, 43(2), 124-129 doi:10.1016/j.enzmictec.2007.11.006

[4] R. Maryana, D. Ma'rifatun, A. Wheni, K. W. Satriyo, W. Angga. Energy Procedia 2014, 47, 250-254.

[5] Y. Sun and J. Cheng. Bioresour. Technol. 2002, 83, 1-11.

[6] H. Bahar, H. Vu-Manh, T. Bechtold. Lenzinger Berichte 2009, 87, 142-150.

[7] O. Yemis, G. Mazza. Bioresour. Technol. 2011, 102, 7371-7378.

[8] F. Nazarpour, D. K. Abdullah, N. Abdullah, R. Zamiri. Materials 2013, 6, 2059-2073.

[9] P. J. Van Soest, R. H. Wine. J. Assoc. Off. Anal. Chem. 1968, 51, 780-785.

[10] E. Alarcón-Gutiérrez, C. Floch, C. Augur, J. Le Petit, F. Ziarelli, S. Criquet. Pedobiologia. 2009, 52, 387-399.

[11] N. Terashima, R. H. Atalla, D. L. Vanderhart. Phytochemistry 1997, 46(5), 863-870.

[12] T. Liitiä, S. L. Maunu, J. Sipilä, B. Hortling. Solid State Nucl. Magn. Reson. 2002, 21(3-4), 171-186

[13] O. Friĉová, M. Koval'aková. ISRN Analytical Chemistry 2013, DOI /10.1155/ 2013/248164

[14] S. L. Maunu. Prog. Nucl. Magn. Reson. Spectrosc. 2002, 40, 151-174.

[15] S. K. Straus, T. Bremi, R. R. Ernst. J. Biomol. NMR. 1997, 10, 119-128.

[16] K. Van de Velde, P. Kiekens. Carbohydr. Polym. 2004, 58, 409-416.

[17] J. M. Yue, S. N. Chen, Z. W. Lin, H. D. Sun. Phytochemistry. 2001, 56, 801806.
[18] F. Wang, Y. Fang, M. Zhang, A. Lin, T. Zhu, Q. Gu, W. Zhu. Steroids. 2008, 73, 19-26.

[19] R. L. Toh Choon, M. Sariah, M. N. Siti Mariam. J. Basic Microbiol. 2012, 52, 608-612.

[20] S. Park, J. O. Baker, M. E. Himmel, P. A. Parrilla, D. K. Johnson. Biotechnol. Biofuels 2010, 3,10 http://www.biotechnologyforbiofuels.com/content/ $3 / 1 / 10$

[21] K. Wickholm, P. T. Larsson, T. Iversen. Carbohydr. Res. 1998, 312, 123129.

[22] H.B. B. Hallac, P. Sannigrahi, Y. Pu, M. Ray, R. J. Murphy, A. J. Ragauskas. J. Agric. Food. Chem. 2009, 57, 1275-1281.

[23] S. Helle, S. J. B. Duff, D. G. Cooper. Biotechnol. Bioeng. 1993, 42(5), 611617.

[24] T. Eriksson, J. Börjesson, F. Tjemeld. Enzyme Microb. Technol. 2002, 31(3): 353-364.

[25] B. Yang, C. E. Wyman. Biotechnol. Bioeng. 2006, 94(4), 611-617.

[26] S. B. Pointing, E. B. G. Jones, L. L. P. Vrijmoed. Mycologia 2000, 92(1), 139-144.

[27] J. Schaefer, E.O.R. , Stejskal. J. Am. Chem. Soc. 1976, 98, 1031-1032.

[28] S. Vikineswary, N. Adbullah, M. Renuvathani, N. Sekaran, A. Pandey, E. B. G. Jones. Bioresour. Technol. 2006, 97, 171-177.

[29] A. Lomascolo, Uzan-Boukhris, I. Herpoël-Gimbert, J-C. Sigoillot, L. Lesage-Meessen. Appl. Microbiol. Biotechnol. 2011, 92, 1129-1149

[30] E. F. A. Smânia, A. Smânia, C. Loguercio-Leite, M. L. Gil. J. Chem. Tec. Biotechnol. 1997, 70, 57-59.

[31] L. H. Rosa, K. M. Gomes, C. C. Jacob, M. Capelari, C. A. Rosa, C. L. Zani. Mem Inst Oswaldo Cruz, Rio de Janeiro 2003, 98(7), 967-974. 